\title{
Development of Belawan's "Marsihaholongan" Batak Toba Dance / Script in the Context of a Plural Community in North Sumatra
}

\author{
Flansius Tampubolon ${ }^{1 *}$, Maurits Junard Pollatu ${ }^{1}$ \\ ${ }^{1}$ Department of regional language, Universitas Sumatera Utara, Medan, Indonesia \\ *Email: tampubolonflansius@gmail.com
}

\begin{abstract}
North Sumatra is one of the provinces in Indonesia which is quite rich in culture including dance. Dance studio is one part of cultural elements that have educational value in the form of function and role in the midst of plural society. Some people of North Sumatra compile and manage dance studios to preserve traditional arts. One of the existing dance studios is the Toba Batak Dance / Aksara "Marsihaholongan". This dance studio is one of the studios in the Bagan Deli area, Belawan. This dance studio began to be made in 2008 with the aim of a place or facility used by the community or a group of people to conduct training activities, namely activities that focus more on the dance field, both traditional and modern dance. This dance studio was created also as a vehicle for the application of harmony among religious believers, not only based on the field of art, but also based on improving culture in plural societies.
\end{abstract}

Keywords: Development of Studio, Culture, Harmony among religions, Compound Society

\begin{abstract}
Abstrak
Sumatera Utara merupakan salah satu provinsi yang di Indonesia yang cukup kaya akan budaya termaksuk seni tari. Sanggar tari merupakan salah satu bagian dari elemen budaya yang memiliki nilai edukatif dalam menjalankan fungsi dan perannya di tengah-tengah masyarakat yang plural. Sebagian masyarakat Sumatera Utara mendirikan dan mengelola sanggar tari untuk melestarikan kesenian tradisional. Salah satu sanggar tari yang ada yaitu Sanggar Tari /Aksara Batak Toba "Marsihaholongan". Sanggar tari ini merupakan salah satu sanggar yang berada di kawasan Bagan Deli, Belawan. Sanggar tari ini mulai dibentuk pada tahun 2008 dengan tujuan untuk tempat atau sarana yang digunakan oleh suatu komunitas atau sekumpulan orang untuk melakukan kegiatan pelatihan seni, yaitu kegiatan yang lebih memfokuskan pada bidang tari, baik tari tradisi maupun tari modern. Sanggar tari ini dijadikan juga sebagai wadah aplikasi kerukunan antarumat beragama, tidak hanya berbasis kepada bidang kesenian saja tetapi juga berbasis kepada peningkatan budaya di masyarakat majemuk.
\end{abstract}

Kata kunci : Pengembangan Sanggar, Budaya, Kerukunan antar umat beragama, Masyarakat Majemuk

\section{PENDAHULUAN (INTRODUCTION)}

Salah satu sifat dari kebudayaan adalah dinamis. Hal ini mengharuskan masyarakat pemilik kebudayaan tersebut untuk selektif dan proaktif dalam menyikapi perkembangan kebudayaannya. Proses dalam pengembangannya, kebudayaan tidak dapat berdiri sendiri tetapi selalu berkaitan dengan hal-hal lain yang terintegrasi dalam kehidupan sosial kemasyarakatan seperti pariwisata. Kebudayaan dan pariwisata harus saling mendukung dan mendorong sehingga pemanfaatan unsurunsur kesenaian dan unsur alami pariwisata harus dilakukan secara bertanggung jawab salah satu contoh integrasi antara unsur kesenian dalam budaya dengan pariwisata adalah seni tari. Royce mengatakan seni tari merupakan salah satu ekspresi estetik manusia dalam bentuk gerak dan telah muncul sejak awal kehidupan manusia. Seni tari memiliki peranan sebagai media ekspresi, berpikir kreatif, mengembangkan bakat dan juga sebagai media komunikasi. Salah satu tempat untuk melestarikan budaya seni tari yaitu sanggar tari. Sanggar merupakan tempat untuk kegiatan 
seni (tari, lukisan,dsb). Dalam sanggar tari, pembelajaran yang dikembangkan adalah mempelajari tari-tarian yang sudah ada baik berupa tari tradisional (klasisk) maupun tari modern atau kreasi. Sanggar tari masih tetap mempertahankan bentuk tari tradisional maupun modern atau juga mengembangkan bentuk-bentuk tari kreasi baru untuk melakukan suatu pertunjukan sebagai bukti keberadaan sanggar tari tersebut hidup ditengah-tengah masyarakat.

Sumatera Utara merupakan salah satu provinsi yang di Indonesia yang cukup kaya akan budaya termasuk seni tari. Sebagian masyarakat Sumatera Utara mendirikan dan mengelola sanggar tari untuk melestarikan kesenian tradisional. Salah satu sanggar tari di Sumatera Utara adalah sanggar tari/aksara Batak Toba "Marsihaholongan." Sanggar tari/aksara Batak Marsihaholongan merupakan salah satu sanggar yang berada di kawasan Bagan Deli, Belawan. Sanggar ini mulai dibuka pada Tahun 2008 dengan tujuan untuk menjaga kearifan lokal adat Batak khususnya dalam Tari/Aksara Batak. Pada Tahun 2010, sanggar ini melakukan pergelaran dan terus berkembang. Sanggar ini didirikan dalam konteks masyarakat yang majemuk, artinya sanggar ini hadir bukan hanya di antara masyarakan atau suku batak saja tetapi sanggar ini hadir di antara berbagai suku maupun agama yang ada di Bagan Deli Belawan.

Keanggotaan sanggar tari ini juga tidak hanya terdiri dari suku batak Toba saja tetapi terdapat juga terdiri dari suka Jawa, Aceh, dan Nias. Bahkan anggota sanggar tari ini pun terdiri dari beberapa agama seperti Nasrani, Katolik, Islam bahkan mencakup agama suku Batak (Parmalim). Hal ini merupakan fenomena yang unik karena tidak seperti biasanya. Akan tetapi, keunikan yang dimiliki sanggar tari/akasara Batak Marsihaholongan tidak bertahan lama. Semenjak pergelaran yang dilakukan pada tahun 2010 silam, keberadaan sanggar ini dapat dikatakan vakum atau redup sampai tahun 2018.

Pada awalnya, sanggar ini didanai secara pribadi oleh bapak Arnold Purba yang sekaligus menjadi pendiri dan pembina sanggar tari tersebut. Perjalanan sanggar ini hanya tergantung kepada undangan atau event yang dilakukan. Kalau tidak ada undangan, maka sanggar tari ini redup. Sekarang ini sanggar tari "Marsihaholongan" mengalami krisis karena antusias masyarakat untuk mengundang sanggar ini sudah menurun. Hal ini disadari oleh bapak Arnold Purba (pendiri sanggar) karena sosialisasi sanggar kepada masyarakat masih sangat kurang. Penampilan yang dilakukan pun mengeluarkan biaya yang begitu besar. Kostum yang dipakai oleh para penari dan pemain musik pada saat pergelaran harus disewa. Hal ini membutuhkan dana yang begitu besar dan uang yang didapat pun tidak begitu besar karena sifatnya sukarela. Ini menjadi kendala utama dalam pengembangan dan pemberdayaan sanggar ditengah-tengah masyarakat. Selain itu, sanggar Marsihaholongan juga belum memiliki sistem pembukuan keuangan yang baik. Yang terjadi selama ini adalah sistem bagi hasil sehingga tidak ada kelancaran perputaran uang karena sudah terbagi habis. Sistem manajemen sanggar Marsihaholongan harus diperbaiki agar sanggar dapat didukung lewat penggunaan keuangan yang tepat guna. 


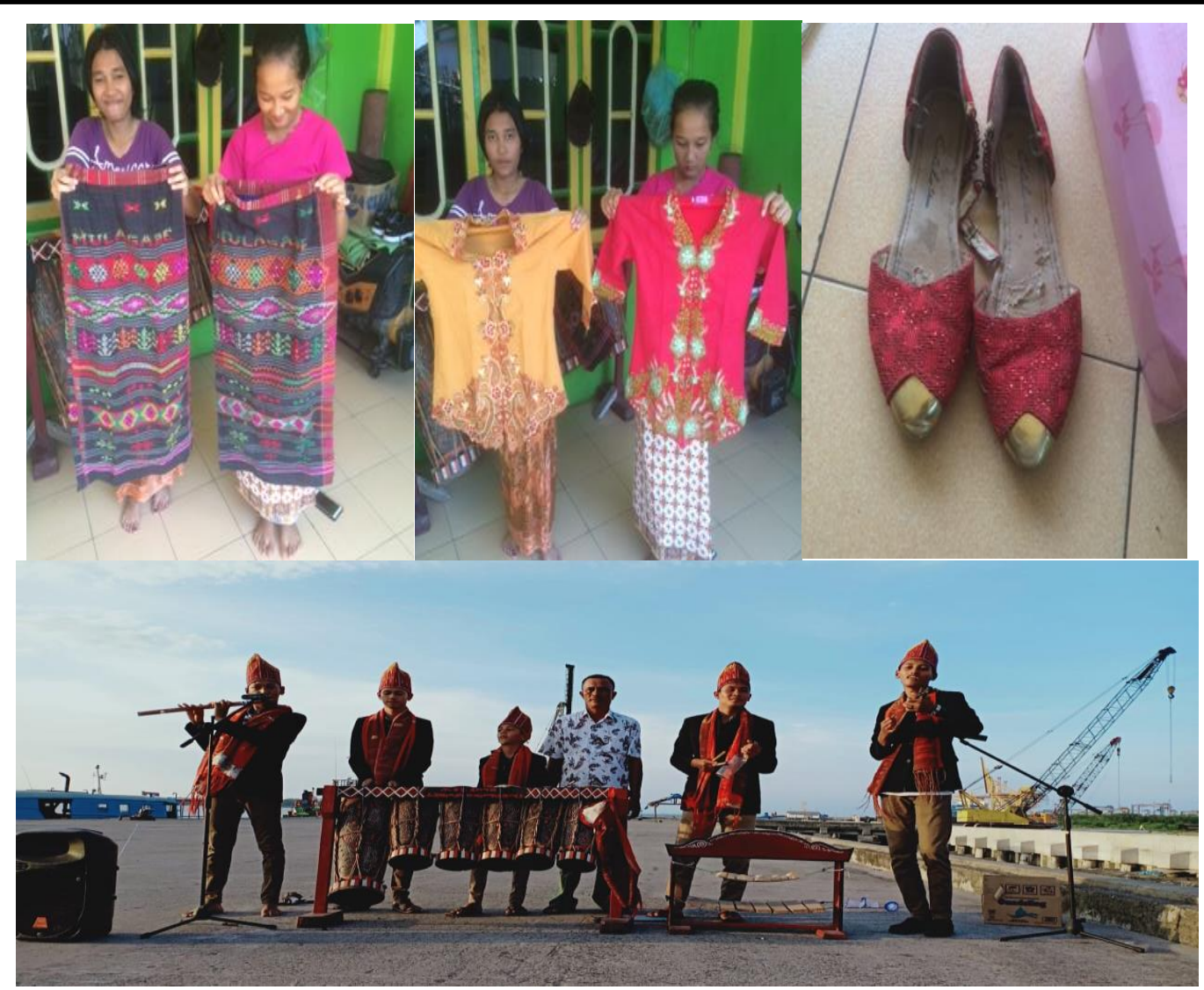

Gambar 1.1 Kostum yang disewa pun sudah kusam

Dengan demikian, sanggar tari "Marsihaholongan mengalami krisis dalam pengembangan dan pemberdayaan di masyarakat. Kearifan lokal yang dipertahankan dan selalu ditampilkan menjadi redup, kesejahteraan masyarakat sekitar yang selama ini cukup dibantu oleh sanggar ini menjadi tidak meningkat.

\section{METODE PELAKSANAAN}

Pada pelaksaan Kegiatan Pengabdian Kepada Masyarakat ini, tim menggunakan beberapa metode dalam membantu pengembangan sanggar tari / aksara Batak Toba Marsihaholongan, yaitu Pengadaan/pembelian kostum bagi para penari dan pemain musik, Pemberian pemahaman melalui kegiatan seminar tentang "Budaya sebagai Dasar Pijak Bersama Antar Umat Beragama," Sosialisasi Sanggar lewat media cetak maupun online, Memberi Pendampingan untuk mengadakan kerjasama (MoU) dengan pihak-pihak terkait, seperti Prodi Sastra Batak Fakultas Ilmu Budaya USU. Pada awal kegiatan, tim turun langsung ke lapangan untuk melakukan observasi dalam bentuk FGD. Setelah melakukan observasi, tim mulai merancang dan merumuskan bentuk kegiatan pengabdian kepada masyarakat dalam berbagai bentuk kegiatan untuk membantu atau mengembangkan sanggar tari/aksara Batak Toba Marsihaholongan.

Selanjutnya metode yang dilakukan oleh Tim adalah pengadaan/penyediaan atau pembelian kostum bagi para penari dan pemain musik. Metode ini dilakukan untuk mengatasi permasalahan sanggar yang melakukan penyewaan kostum ketika mengadakan pergelaran atau pertunjukan. Dalam hal ini, sanggar dapat memiliki barang iventaris sanggar tari serta tidak mengeluarkan biaya yang besar untuk menyewa kostum dalam melakukan pertunjukan.

Metode berikutnya adalah pemberian pemahaman melalui kegiatan seminar tentang "Budaya sebagai Dasar Pijak Bersama Antar Umat Beragama." Hal ini dilakukan berkaitan dengan konteks 
situasi nasional yang belakangan ini marak terjadi yaitu sikap intoleran antar umat beragama pada masyarakat Indonesia. Tim mencoba memberikan pemahaman bagi para anggota sanggar bahwa sanggar tari/akasara Batak Toba memiliki peran dan fungsi yang luas pada er postmodern sekarang ini. Sanggar tidak hanya dilihat sebagai tempat ekspresi seni yang hanya dibatasi pada tari-tarian, tetapi sanggar tari lebih dilihat sebagai laboratorium kerukunan antar umat beragama, di mana budaya menjadi dasar pijak bersama antar umat beragama. Hal ini dilakukan agar sanggar tari tersebut dapat berkembang dan menjadi jawaban bagi pergumulan masyarakat khususnya dalam kemajemukan agama dan budaya dewasa ini.

Metode terakhir adalah sosialisasi sanggar tari lewat media cetak maupun online dan memberi Pendampingan untuk mengadakan kerjasama (MoU) dengan pihak-pihak terkait, seperti Program Studi Sastra Batak Fakultas Ilmu Budaya - USU. Hal ini dilakukan agar sanggar tari/aksara Batak Toba Marsihaholongan dikenal secara umum baik lewat lembaga pendidikan yang terkait, media cetak, maupun media online. Hal ini merupakan salah satu kiat yang dilakukan oleh tim dalam mengembangkan sanggar tersebut.

\section{HASIL DAN PEMBAHASAN}

Hasil dan pembahasan pengabdian kepada masyarakat dengan menggunakan metode yang diterapkan pada sub bab sebelumnya adalah :

1) Pengembangan Sanggar Melalui Pengadaan Kostum Penari dan Pemain Musik

2) Seminar "Budaya Sebagai Dasar Pijak Bersama Antar Umat Beragama"

3) Sosialisasi program dari sanggar lewat media cetak/online

4) Memberi Pendampingan untuk mengadakan kerjasama (MoU) dengan pihak-pihak terkait, seperti Prodi Sastra Batak Fakultas Ilmu Budaya - USU

\section{KESIMPULAN}

Pengabdian kepada masyarakat merupakan salah satu kegiatan Tri Dharma Perguruan tinggi yang sangat bermanfaat bagi kehidupan masyarakat khususnya bagi masyarakat yang membutuhkan bantuan dari Pemerintah. Saran dari pelaksana pengabdian, semoga pengabdian kepada masyarakat yang membutuhkannya dapat berkesinambungan pada tahun-tahun berikutnya.

\section{UCAPAN TERIMAKASIH}

Artikel ini merupakan salah satu hasil dari Program Pengabdian kepada Masyarakat yang Dibiayai oleh dana NON PNBP Universitas Sumatera Utara Sesuai dengan Surat Perjanjian Penugasan Pelaksanaan Pengabdian kepada Masyarakat Program Mono Tahun Dosen Muda Tahun Anggaran 2019. Oleh karena itu, diucapkan terima kasih kepada Rektor Universitas Sumatera Utara atas dukungan dana dan fasilitas yang diberikan. Terima kasih juga kepada Mitra pada kegiatan pengabdian ini.

\section{DAFTAR PUSTAKA}

Astuti Fuji, 1996. Pengetahuan \& Teknik Menata Tari: Untuk Anak Usia Dini. Bandung: Pakar Raya.

Jazuli, M. 1999. Telaah Teoritis seni Tari, Semarang: IKIP Semarang Press 
Flansius et.al Development of Belawan's

Lembaga Pengabdian Kepada Masyarakat, Pedoman Penyusunan Proposal Pengabdian Kepada Masyarakat Sumber Dana Non PNBP USU Tahun Anggaran 2019 Edisi 3 (Medan: Lembaga Pengabdian KepadaMasyarakat USU) 2019.

Mustajab Andi, Sistem Manejemen Sanggar Seni Ambararala Kecamatan Bunggoro, Kebudayaan Pangkep (Makasar: Prodi Pendidikan Sendratasik, Fakultal Seni dan Design, Universitas Negeri Makasar) 2013.

Purba, Mauly. 2012. Mengenal Tradisi Gondang dan Tortor Batak Toba. Medan: Universitas Sumatera Utara. 